\title{
RAPID DIAGNOSIS OF VESICULAR STOMATITIS VIRUS IN ECUADOR BY THE USE OF POLYMERASE CHAIN REACTION
}

\author{
Lya Madureira Sepúlveda ${ }^{1}$; Viviana Malirat ${ }^{1 *}$; Ingrid E. Bergmann ${ }^{1}$; Anibal Mantilla²; \\ Elmiro Rosendo do Nascimento ${ }^{3}$
}

\begin{abstract}
${ }^{1}$ Centro Pan-Americano de Febre Aftosa (OPS/OMS), Rio de Janeiro, RJ, Brasil; ${ }^{2}$ Instituto Nacional de Higiene y Medicina, Ecuador; ${ }^{3}$ Laboratório de Epidemiologia Molecular, Departamento de Saúde Coletiva Veterinária e Saúde Pública, Universidade Federal Fluminense, Niterói, RJ, Brasil
\end{abstract}

Submitted: November 07, 2006; Returned to authors for corrections: February 02, 2007; Approved: July 16, 2007.

\begin{abstract}
Vesicular Stomatitis (VS) is a viral disease that has a great impact in animal health, as infected animals present marked decrease in meat and milk production. Its presence is a limiting factor for international animal trade. Besides the damage in the livestock productivity, such disease assumes an important role in animal health programs since it is clinically indistinguishable from Foot-and-Mouth Disease. The diagnosis of the VS has been made, mainly, through Complement Fixation, ELISA and Virus Neutralization tests, assays that allow not only for viral detection but also for differentiation of the two serotypes described for Vesicular Stomatitis Virus (VSV): New Jersey (NJ) and Indiana (Ind). In this work, a molecular diagnostic approach, the polymerase chain reaction performed after reverse transcription (RT - PCR), based on the specific partial amplification of NS gene of VSV was used, as an alternative method for the detection of the virus. A total of $10 \mathrm{VSV}$ reference samples and 12 specimens collected from animals with clinical signs of vesicular disease obtained from field episodes in Ecuador were tested. The method allowed for the specific partial amplification of the region coding for protein P, both for VSV serotypes New Jersey (642 bp) and Indiana 1 (614 bp). The results were compatible with data obtained by Complement Fixation test and the identity of the amplified products was confirmed by nucleotide sequencing.
\end{abstract}

Keywords: Polymerase Chain reaction; Vesicular Stomatitis; molecular diagnosis.

\section{INTRODUCTION}

Vesicular Stomatitis (VS) is an acute viral disease of a wide range of mammals including equine, cattle and swine, caused by a virus of the Rhabdoviridae family, Vesiculovirus genus, the Vesicular Stomatitis virus (VSV) (8). There are two major serotypes of VSV: New Jersey (NJ) and Indiana (Ind); the latter one including subtypes: Ind 1, Ind 2 and Ind 3 (10). VS is restricted to the Western Hemisphere, presenting endemic activity most commonly from northern South America to northern Mexico and southeast of the United States. Epidemic activity can be registered in southern South America, United States and Canada (3).
Clinical signs of the disease include vesicular lesions and ulcerations of the tongue, oral tissues and coronary bands, and except for its appearance in horses, it is clinically indistinguishable from foot-and-mouth disease (FMD), one of the most devastating viral infections in livestock, which makes laboratory diagnosis often necessary to differentiate between the two diseases (2). This fact, together with its obligatory report to the World Organization of Animal Health (OIE) (15), illustrates the importance of a conclusive diagnosis of VS for animal health programs. This is particularly evident in regions where programs to eradicate FMDV have been implemented, including vaccination and movement control, as in South America. As mentioned before, VS occurs

*Corresponding Author. Mailing address: Centro Pan-Americano de Febre Aftosa (OPS/OMS), Caixa Postal 589. CEP:20010-974. Rio de Janeiro, RJ, Brasil. Tel: (55) (21) 3661.9080; Fax: (55) (21) 3661.9001. E-mail: vmalirat@panaftosa.ops-oms.org 
endemically in northern South America, therefore, in these regions the precise diagnosis of VSV is of utmost importance. In countries in the northern Andean Region (Colombia, Ecuador and Peru) about 340 outbreaks of VS are registered annually, mainly NJ, and in a smaller proportion, Ind 1. In southern Ecuador serotypes $\mathrm{NJ}$ and Ind 1 present endemic activity (12).

Available tools for VSV diagnosis are the identification/ isolation of the agent, which can be achieved through inoculation in several cell culture lines, in unweaned mice or even in embryonated chicken eggs. Viral antigens can be identified by complement fixation $(\mathrm{CF})(1,4)$, indirect sandwich enzyme-linked immunosorbent assay (ELISA) (2), immunofluorescence using monoclonal antibody and virus neutralization tests $(1,4)$. All these methods are laborious and time-consuming. Achievement of a rapid diagnosis can be obtained by molecular technology methods, like the polymerase chain reaction (PCR), applied to amplify part of the VS viral genome. This fast and sensitive diagnosis method is being used as an aid in the diagnosis of a growing number of infectious agent's diseases. The detection of VSV through the amplification of the genomic material using the reverse transcription of the viral RNA followed by PCR method (RT-PCR) has been described in the literature $(7,11,13)$.

The present study describes the use of the RT - PCR technique for the diagnosis of VSV directly from epithelial samples collected during outbreaks registered in 2004 in Ecuador. The results obtained for the RT-PCR specific amplification of part of the region coding for VSV protein P (serotypes NJ and Ind 1) for a total of $10 \mathrm{VSV}$ reference samples and 12 field materials collected from animals with clinical signs of vesicular disease, are presented. The nucleotide sequences obtained to confirm the specific amplified materials are also included.

\section{MATERIALS AND METHODS}

\section{Viral isolates and sample preparation}

Cell culture-grown isolates of VSV reference strains (NJ Costa Rica/66, NJ Ecuador/85, Ind1 Costa Rica/72, Ind1 El Salvador/71, Ind1 El Salvador/78, Ind1 Costa Rica/79, Ind2 Rancharia Brasil/66, Ind2 Ribeirão Brasil/79, Ind3 Ag. Negras Brasil/86, Ind3 Espinosa Brasil/77) maintained at PANAFTOSA (12) were used for the evaluation of the method used in this study. Also analyzed were epithelial samples sent to PANAFTOSA inactivated in Trizol Reagent (Invitrogen), collected during outbreaks of vesicular disease in 2004 in Ecuador (Table 1), and recording VSV positive by CF, serotypes NJ and Ind1. Additionally two epithelial samples (029-4 and 029-12) with negative results for VSV by CF were include in the analisys. Moreover, foot-and mouth-disease viral strains A24 Cruzeiro Br 1/55, O1 Campos Br 1/58 and C3 Indaial $\mathrm{Br} 1 / 71$ were tested to evaluate the specificity of the VSV-specific primers.

Total RNA was directly extracted from cell culture or epithelium samples using the Trizol Reagent according to the manufacturer's instructions. RNA pellets were resuspended in 20-50 $\mu$ l of RNAse-free sterile water (Sigma).

\section{Oligonucleotide primers}

Two pairs of oligonucleotide primers (13) were used in this study, which specifically amplified fragments within the gene coding for the VSV phosphoprotein (gene NS), rendering amplification fragments of $642 \mathrm{bp}$ for $\mathrm{NJ}$ and $614 \mathrm{bp}$ for Ind 1. Primers are complementary to the flanking regions between positions 102 (P-NJ 102, 5' GAGAGGATAAATATCTCC 3') and 744 (P-NJ 744, 5' GGGCATACTGAAGAATA 3') of the published sequence of VSV New Jersey (Genebank accesion number:

Table 1. Designation and origin of field samples studied.

\begin{tabular}{ccccccc}
\hline Virus designation & Identification & Location & Sample & CF $*$ & Database & Reference \\
\hline NJ Ecuador/04(2) & $029-2$ & Napo & Bovine Tongue Epithelium & NJ & EF028141 & This work \\
NJ Ecuador/04(3) & $029-3$ & Cotopaxi & Bovine Tongue Epithelium & NJ & EF028142 & This work \\
Ind Ecuador/04(5) & $029-5$ & Loja & Bovine Tongue Epithelium & Ind & EF028138 & This work \\
NJ Ecuador/04(6) & $029-6$ & Los Rios & Bovine Tongue Epithelium & NJ & EF028143 & This work \\
NJ Ecuador/04(8) & $029-8$ & Cotopaxi & Bovine Tongue Epithelium & NJ & EF028144 & This work \\
NJ Ecuador/04(9) & $029-9$ & Cotopaxi & Bovine Epithelium & NJ & EF028145 & This work \\
NJ Ecuador/04(10) & $029-10$ & Pichincha & Bovine Epithelium & NJ & EF028146 & This work \\
NJ Ecuador/04(11) & $029-11$ & Los Rios & Bovine Tongue Epithelium & NJ & EF028147 & This work \\
NJ Ecuador/04(18) & $029-18$ & Orellana & Bovine Buccal epithelium & NJ & EF028148 & This work \\
NJ Ecuador/04(19) & $029-19$ & Pichincha & Bovine Buccal epithelium & NJ & EF028149 & This work \\
NJ Ecuador/04(20) & $029-20$ & Guayas & Epitélio Gengival Bovino & NJ & EF028150 & This work \\
NJ Ecuador/04(33) & $029-33$ & Pichincha & Bovine Buccal epithelium & NJ & EF028151 & This work \\
\hline
\end{tabular}

$\mathrm{CF}$ : Complement fixation $(\mathrm{CF})$ test. 
M31868) and positions 179 (P-Ind 179, 5' GCAGATGATTC TGACAC 3' ) and 793 (P-Ind 793, 5' GACTCT(C/T)GCCTG(A/ G)TTGTA 3') of the published sequence of VSV Indiana 1 (Genebank accesion number X04453). The primers were used for the amplification as well as for the sequencing reactions

\section{Reverse Transcription and Polymerase Chain Reaction (RT-PCR)}

For cDNA synthesis the viral RNAs ( $5 \mu \mathrm{l})$ were incubated at $42^{\circ} \mathrm{C}$ for 60 min using $50 \mathrm{ng}$ of random primers in $25 \mu$ final volume reaction mix containing $20 \mathrm{mM}$ Tris- $\mathrm{HCl}(\mathrm{pH}$ 8.4), 50 $\mathrm{mM} \mathrm{KCl}, 2.5 \mathrm{mM} \mathrm{MgCl}_{2}, 10 \mathrm{mM}$ dithiothreitol, $0.6 \mathrm{mM}$ each dNTPs and 50 units of Superscript II reverse transcriptase (préamplification system Superscript for RT-PCR, Invitrogen). In vitro amplification was carried out in a programmable thermocycler GeneAmp PCR system 9700 (Perking Elmer, Branchburg, NJ, USA). Each reaction was performed in of $50 \mu \mathrm{l}$ final volume reaction mix containing: $5 \mu \mathrm{cDNA}, 25 \mathrm{pmol}$ of each primer, 2.5 units of Thermus aquaticus polymerase (Invitrogen), $0.2 \mathrm{mM}$ each dNTP (dATP, dCTP, dGTP, dTTP), $1.5 \mathrm{mM} \mathrm{MgCl}_{2}, 20 \mathrm{mM}$ Tris- $\mathrm{HCl}$, (pH 8.3), and $50 \mathrm{mM} \mathrm{KCl}$. After denaturation for $3 \mathrm{~min}$ at $94^{\circ} \mathrm{C}$ the mixtures were incubated for 40 cycles at $93^{\circ} \mathrm{C}$ for $1 \mathrm{~min}, 50^{\circ} \mathrm{C}$ for $1 \mathrm{~min}$ and $72^{\circ} \mathrm{C}$ for $1 \mathrm{~min}$, followed by a final extension at $72^{\circ} \mathrm{C}$ for $5 \mathrm{~min}$. PCR products were analyzed by electrophoresis in $2 \%$ agarose gels containing $0.5 \mu \mathrm{g} / \mathrm{ml}$ of ethidium bromide.

\section{Automated sequencing of amplified products}

The amplified products were purified by sizing (band excision) from $1 \%$ agarose gels followed by chromatography in affinity columns (Concert Rapid Gel Extraction System- Life Technology) and the recovered material was quantified by band intensity comparison with DNA mass and molecular weight marker (Invitrogen) in 1\% agarose gel electrophoresis.

The nucleotide sequences were determined using 20-60 ng of the purified amplicon, with the Big Dye Terminator kit (Applied Biosystems), according to the manufacturer's instructions, with minor modifications (9) in a termocycler, performing 40 cycles of $94^{\circ} \mathrm{C}, 45 \mathrm{sec} . ; 50^{\circ} \mathrm{C}, 30 \mathrm{sec} . ; 60^{\circ} \mathrm{C}, 4 \mathrm{~min}$. Each sequence was determined in two individual reactions with the sense and antisense primers specific for each serotype; and were repeated twice. The reaction products were purified by exclusion chromatography (CentriSep columns, Princeton Separations); the recovered material was dried and ressuspended in $10 \%$, formamide for reading in an ABI Prism 3100 Avant automated sequencing machine, as recommended by the manufacturers. The accessions numbers of the sequences determined in this study are listed in Table 1. Nucleotide sequences were analyzed on an IBM compatible personal computer using the program BioEdit (5) for editing and alignment. Sequences obtained were compared to those already published in GenBank, with accesion numbers M31868 (NJ) and X04453 (Ind1).

\section{Analytical sensitivity}

Serial dilutions of RNA extracted from the supernatant of BHK cell monolayer infected with the reference samples NJ CR $/ 66\left(10^{8} \mathrm{TCID}_{50} / \mathrm{ml}\right)$ and $\mathrm{Ind} \mathrm{CR} / 72\left(10^{8,25} \mathrm{TCID}_{50} / \mathrm{ml}\right)$ were used to determine the analytical sensitivity of the RT-PCR performed in this work. $\mathrm{TCID}_{50}$ was obtained by virusneutralization as previously described (1).

\section{RESULTS}

\section{Detection of specific VSV genomic sequences from field samples by RT-PCR}

RNA was successfully extracted using Trizol, either from virus-infected cell culture suspensions (reference samples) or from clinical specimens (epithelium).

RT-PCR amplification of reference samples using the serotype specific primers described, rendered typical positive reactions both for VSV-NJ strains: NJ Costa Rica/66 (Fig. 1-A) and NJ Ecuador/85, (642-bp product band), as well as for VSV Ind1 strains: Ind1 Costa Rica/72 (Fig. 1-B), Ind1 El Salvador/71, Ind1El Salvador/78, and Ind1 Costa Rica/79 (614-bp product band). No cross reactions were observed in the RT-PCR with NJ and Ind1 strains when using primers specific for Ind1 and NJ, respectively. Amplification was not observed for serotypes Ind2 and Ind3 (samples Ind2 Rancharia Brasil/66, Ind2 Ribeirão Brasil/ 79, Ind3 Ag. Negras Brasil/86, Ind3 Espinosa Brasil/77) with any pair of primers. FMDV samples resulted negative for RTPCR for both primer pairs.

Amplification was then performed in the RNA extracted from field samples from Ecuador. All $11 \mathrm{NJ}$ samples rendered bands of the expected size, $642 \mathrm{bp}$, as can be seen in Fig. 1A. These samples did not give amplification products when tested with specific Ind1 primer pair. The only Ind 1 sample (029-5, as characterized by CF test) specifically amplified with Ind1 primer pair, generating a band of the expected size (614 bp, Fig. 1-B), and giving no amplification with the primers specific for NJ serotype two samples that were negative by CF (029-4 and 029-12) did not amplified specific NJ or Ind1 fragments by PCR.

\section{Nucleotide sequences of the amplified products}

To confirm the identity of the amplified products, the amplicons obtained were purified and further sequenced. A total of 18 partial sequences of the NS gene were obtained. Sequences covered nucleotides 134 to 698 of the NS gene for NJ serotype (Fig. 2-A) and 199 to 678 for type Ind1 (Fig. 2-B). Comparison of these sequences with those available for VSV NJ and Ind1 in the Genebank (Fig. 2) confirmed that the amplified fragments corresponded to partial sequences of the NS gene both for samples of NJ and Ind1 serotypes. Sequences were also obtained for the South American VSV NJ and Ind1 reference strains (Fig. 2). 

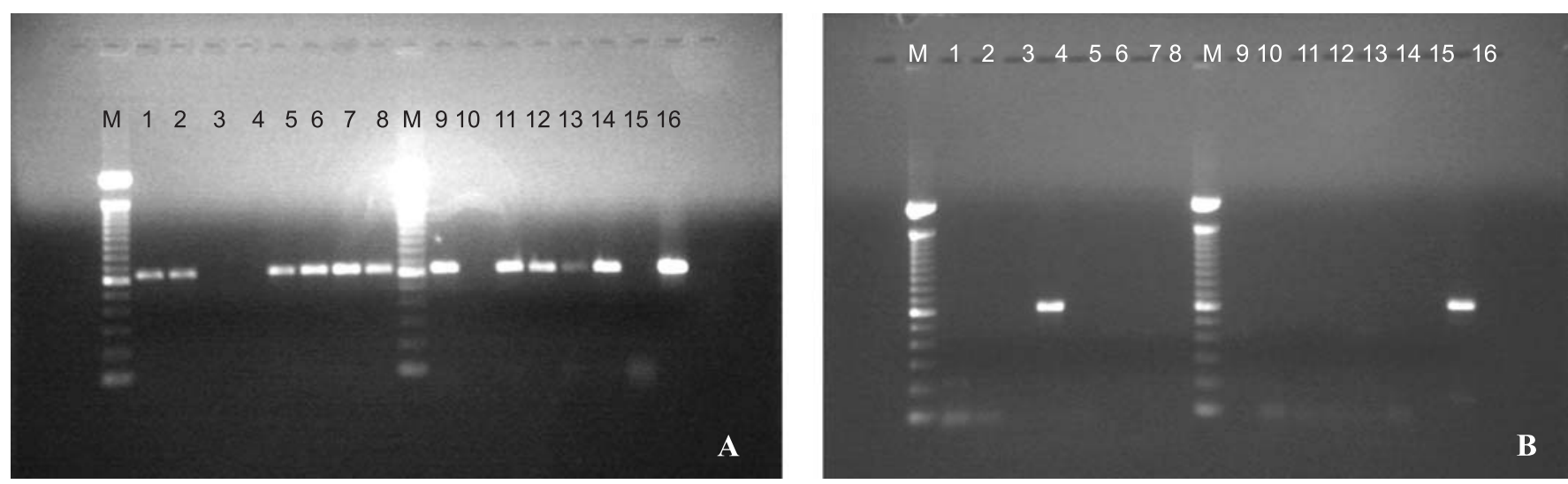

Figure 1. Agarose gel electrophoresis of RT-PCR products obtained from isolates in Ecuador, and from reference samples amplified with primer pairs specific for $\mathrm{NJ}$ (A) or Ind (B). Lanes 1 to 14: isolates 029-2, 3, 4, 5, 6, 8, 9, 10, 11, 12, 18, 19, 20, 33; lane 15: negative control; lane 16: reference sample NJ CR /66 (A) and Ind CR /72 (B); lane M: molecular weight marker (100 bp).

\section{Analytical Sensitivity of the RT- PCR}

To estimate the sensitivity with which the primers tested can amplify fragments of VSV NJ and Ind1 strains, serial dilutions covering a range from $10^{-1}$ to $10^{-7}$ of the reference samples NJ Costa Rica/66 and Ind1 Costa Rica/72 were tested in the RT-PCR assay. Sample NJ Costa Rica/66 gave detectable amplification bands from up to $10^{-5}$ dilution (Fig. 3-A), giving relative sensitivity of up to $250 \mathrm{TCID}_{50}$ (using primers NJ 102 / 744). For sample Ind 1 Costa Rica/72, the last dilution that gave detectable band was $10^{-3}$ (Fig. 3-B), corresponding to a relative sensitivity of $4,445 \mathrm{TCID}_{50}$.

\section{DISCUSION}

Diagnosis of VS is based on the recognition of clinical signs, virus isolation and antigen detection. ELISA tests are available for the detection of viral antigens (2). However, many times field samples from suspect animals may not contain sufficient viral material to be directly detected in the ELISA. In these cases viral isolation can be attempted, but usually several days are needed for cythopatic effect to be observed. The RT-PCR is an additional method that can be used to diagnose VSV and to identify NJ and Ind1 serotypes, being the former one the prevalent type of VSV presently circulating in the Andean region of South America.

RT-PCR techniques for the detection of VSV have been previously described $(7,11,13)$. However, little evaluation on their performance in circulating VSV strains in South America is available.

Results from this study showed that the primers used could specifically amplify a region of the VSV NS gene of Ecuadorian strains being capable of discriminating between serotypes $\mathrm{NJ}$ and Ind1. The oligonucleotide primers proved to be specific for VSV as they failed to amplify viral RNAs from other viruses that cause vesicular disease, like foot-and-mouth disease virus. Lack of specific amplification of VSV genome fragments in specimens 029-4 and 029-12 is not necessarilly to due to a failure of sensitivity of the assay, as these vesicular specimens were also negative by $\mathrm{CF}$ test for both serotypes.

No primer pairs analyzed, including other studied in previous works with RT-PCR techniques already described $(7,11)$ - data not shown - were capable of amplifying VSV serotypes Ind2 and Ind 3 . In fact, Ind 2 and Ind 3 show a distant relationship with respect to Ind 1, and are quite distinct from NJ (4), which has prompted the proposal of a new classification in which subtypes Ind 2 (Cocal) and Ind 3 (Alagoas) would be classified as species (8). For this detection to be accomplished, more studies need to be done, varying the cycle temperatures and conditions, and even including the design of new oligonucleotides. In spite of the importance of detecting the Ind 2 and Ind 3 serotypes it is relevant to mention here that types NJ and Ind1 are the responsible for over 90\% (12) of the VSV outbreaks recorded in our Continent (12)

The standardization done with primers that recognize the gene that codifies for the $\mathrm{P}$ protein allows for the use of these sequences in phylogenetic studies that could aid to understand the mechanisms and factors involved in the epidemiology of this virus in that area $(13,14)$.

The analytical sensitivity study performed in this work suggests that with the use of this protocol approximately 250 TCID $_{50}$ of VSV serotype NJ can be identified, as detected by ethidium bromide staining, which is comparable to the sensitivity described in the literature. In the case of Ind1 a much less sensitivity was found, being estimated in about only 4,445 TCID $_{50}$. Although the sensitivity of this assay can be improved potentially by nested formats, a RT- PCR using a single amplification will be less prone to contamination. In most cases the concentration of virus from infected tissues is $10^{5} \mathrm{TCID}_{50}$, clearly above the detection limit of these assays. 
RNA extraction using Trizol showed to be a fast and simple procedure to obtain good quality VS viral RNA from suspension of infected cell cultures as well as from epithelial samples, including different types of epithelia. This is quite relevant, as it allows for virus detection directly from epithelium, avoiding the need to perform passages of the sample in cell cultures, which is a time-consuming process, delaying a conclusive diagnosis and hindering the sanitary measures. Another advantage is that some contaminants present in samples from treated vesicular lesions that may interfere with CF test and cell culture based assays do
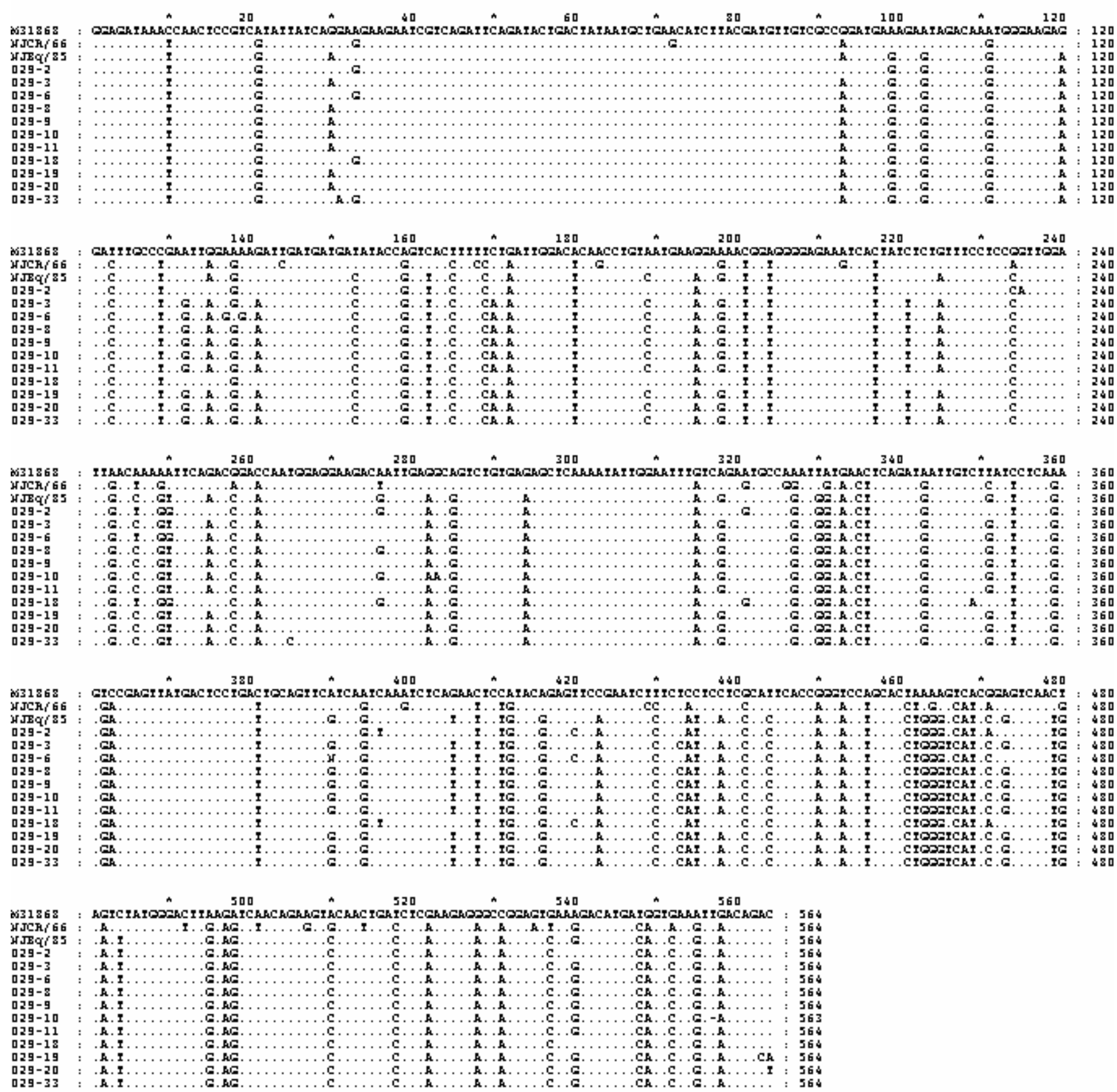

Figure 2-A. Partial nucleotide sequences of the purified amplicons shown in Figure 1A. Sequences obtained covered nucleotides 134 to 698 of the NS gene for NJ serotype (Genebank accession numbers for reference samples are: NJ CR/66: EF 028139 and NJ Eq/ 85: EF 028140). 


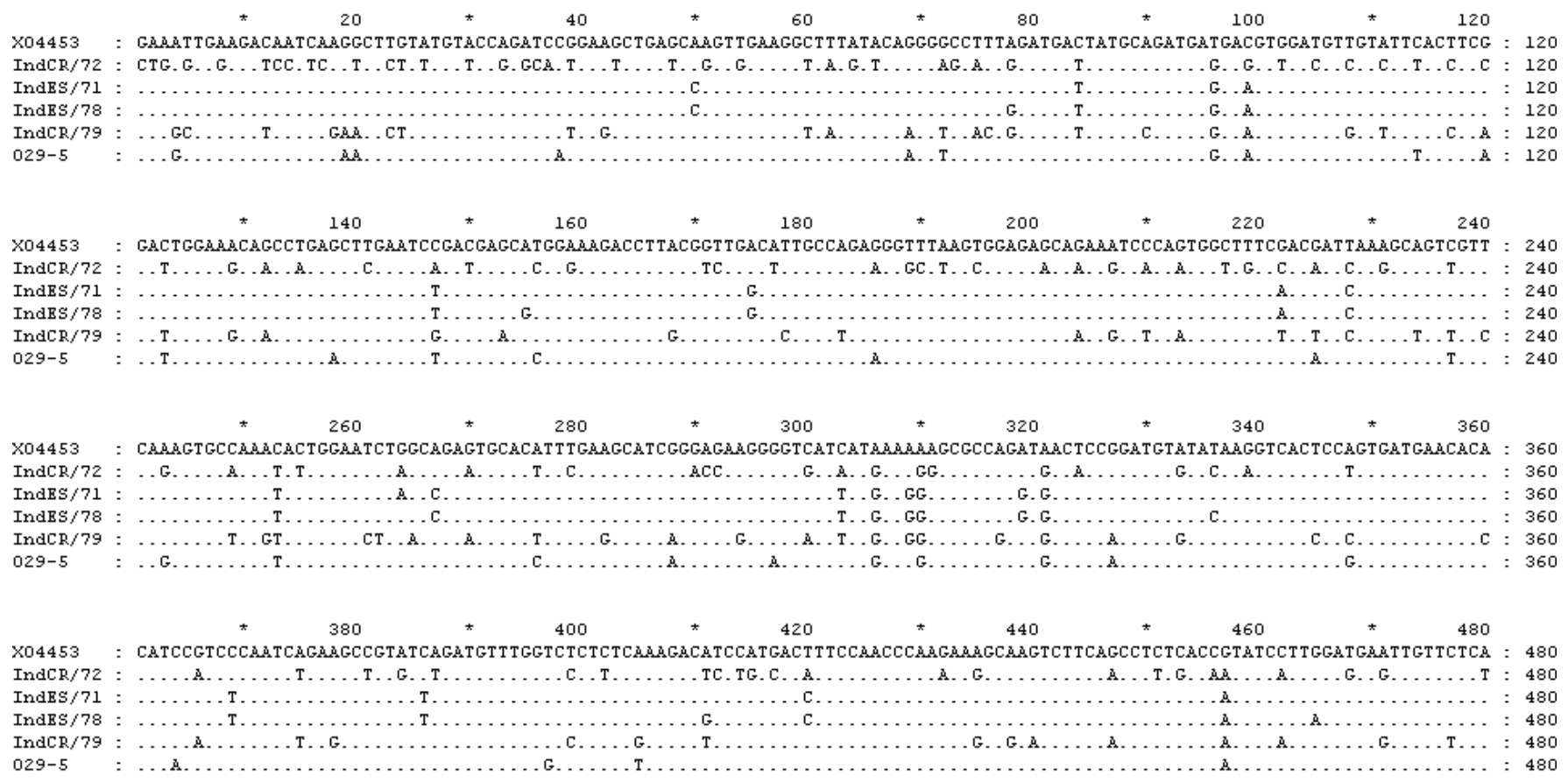

Figure 2-B. Partial nucleotide sequences of the purified amplicons shown in Figure 1B. Sequences obtained covered nucleotides 199 to 678 of the NS gene for Ind 1 serotype. (Genebank accession numbers for reference samples are: Ind CR/72: EF 028134; Ind ES/71: EF 028135; Ind ES/78: EF 028136 and Ind CR/79: EF 028137).

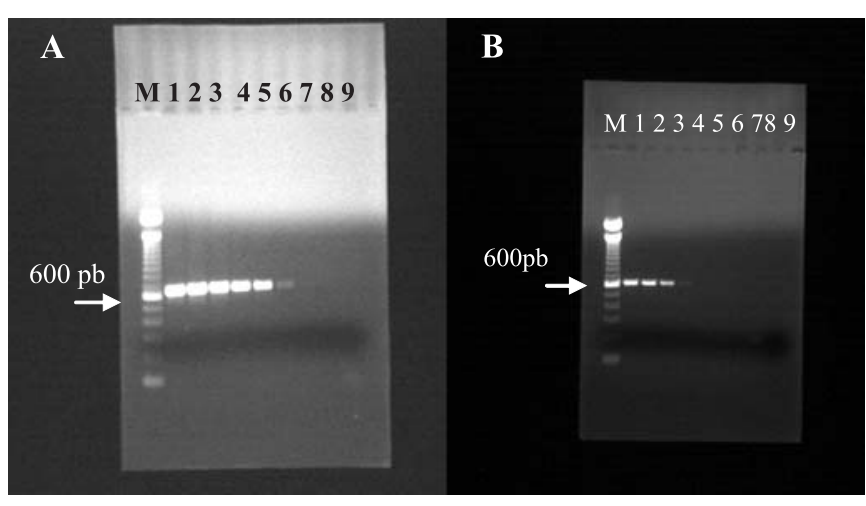

Figure 3. Analytical sensitivity of RT-PCR NJ (A) and Ind 1 (B): Serial ten-fold dilutions of total RNA extracted from BHK21 cells infected either with VSV-NJ /66 (A) or Ind CR /72 (B) and amplified by RT-PCR as described in materials and methods. Starting material in lane1: undiluted RNA and in lanes 2 to 8 RNA serial dilutions $10^{-1}$ to $10^{-7}$ respectively; lane 9: negative control.

not seem to affect the RT-PCR method (13). Moreover the use of Trizol as inactivant enables laboratories with no bio-containment facilities to work with this type of sample (6); this is particularly important when vesicular diseases are involved, particularly as FMDV will also be inactivated by this reagent.

It is not expected that a definitive diagnosis of VSV will be based solely on PCR results. However, PCR will contribute significantly to the establishment of a rapid definitive diagnosis in association with other well developed tests like ELISA for antigen detection or virus isolation techniques.

The use and implementation of RT-PCR for the rapid diagnosis of VSV will strengthen the animal health programs particularly at international borders as well as to improve the diagnostic capability of reference laboratories across South America

\section{RESUMO}

\section{Diagnóstico rápido do vírus da estomatite vesicular no Equador mediante o uso da reação em cadeia da polimerase}

A Estomatite Vesicular (EV) é uma enfermidade viral de grande impacto na saúde animal. O animal enfermo apresenta queda na produtividade em rebanho de carne e na produção leiteira, sendo um fator limitante para o comércio internacional de animais. Além dos danos à produtividade essa enfermidade 
assume importante papel nos programas de saúde animal por ser indistinguível clinicamente da Febre Aftosa. As técnicas para o diagnóstico da EV são, principalmente, a Fixação de Complemento, a ELISA e a Virusneutralização, testes que permitem a detecção viral e a diferenciação dos dois sorotipos descritos para o vírus da Estomatite Vesicular (VEV): New Jersey (NJ) e Indiana (Ind). Neste trabalho a metodologia molecular da reação em cadeia da polimerase após transcrição reversa (RT PCR) baseada na amplificação parcial específica do gene NS do VEV foi utilizada como um método alternativo para a detecção do vírus. Um total de 10 amostras de referência do VEV e 12 espécimes coletados de animais com sinais clínicos de enfermidade vesicular obtidas de episódios de campo em Equador foi testado. O método permitiu a amplificação parcial da região que codifica para proteína $\mathrm{P}$, tanto para NJ (642 pb) quanto para Ind (614 pb). Os resultados foram concordantes com os dados obtidos por Fixação de Complemento e a identidade dos produtos amplificados foi confirmada por meio de seqüenciamento nucleotídico.

Palavras-chave: Reação em Cadeia da Polimerase; Estomatite Vesicular; Diagnóstico molecular.

\section{REFERENCES}

1. Alonso, F.A. (1996). Manual de diagnostico de laboratorio de las enfermedades vesiculares. Centro Panamericano de Fiebre AftosaOPS/OMS, Rio de Janeiro.

2. Alonso, A.; Martins, M.A.; Gomes, M.P.D.; Allende, R.; Söndahl, M.S. (1991). Development and evaluation of an enzyme-linked immunosorbent assay for detection, typing and sub typing of vesicular stomatitis virus. J. Vet. Diagn. Invest., 3, 287-292.

3. Arboleda, J.J.; Trujillo, C.M. (2002). La estomatitis vesicular: algunos aspectos históricos, clínicos, eco-epidemiológicos virológicos, de prevención y control. Rev. Colombiana Cienc. Pec., 15(3), 356-367.

4. Federer, K.E.; Burrows, R.; Brooksby, J.B. (1967). Vesicular stomatitis virus the relation between some strains of the Indiana serotype. Res.Vet. Sci., 8, 103-117.

5. Hall, T.A. (1999). BioEdit: a user-friendly biological sequence alignment editor and analysis program for Windows 95/98/NT. Nucleic Acids Symp. Ser. 41, 95-98.

6. Hofnann, M.A.; Thür, B.; Liu, L.; Gerber, M.; Stettler, P.; Moser, C.; Bossy, S. (2000). Rescue of infectious classical swine fever and footand-mouth disease virus by RNA transfection and virus detection by RT-PCR after extended storage of samples in Trizol. J. Virol. Methods, 87, 29-39.

7. Hofner, M.C.; Carpenter, W.C.; Ferris, N.P.; Kitching, R.P.F.; Ariza Botero, F. (1994). A hemi-nested PCR assay for the detection and identification of vesicular stomatitis virus nucleic acid. J. Virol. Methods, 50, 11-20.

8. ICTVdb: International Committee on Taxonomy of Viruses. Available at: http://www.ncbi.nlm.nih.gov/ICTVdb/. Accessed 10 jun 2006.

9. Malirat, V.; Bergmann, I. (2003). Fiebre aftosa. Instrumentos moleculares para caracterización viral. Centro Panamericano de Fiebre Aftosa-OPS/OMS, Rio de Janeiro.

10. Mason, J. (1978). The epidemiology of vesicular stomatitis. Bol. Cent. Panamer. Fiebre Aftosa, 29-30, 35-53.

11. Nüñez, J.I.; Blanco, E.; Hernádez, T.; Gómes-Tejedor, C.; Martín, M.J.; Dopazo, J.; Sobrino, F. (1998). A RT-PCR assay for the differential diagnosis of vesicular viral diseases of swine. J. Virol. Methods, 72, 227-235.

12. PANAFTOSA: Pan American Foot-and-Mouth Disease Center. Annual Reports. Available at: http://www.panaftosa.org.br. Accessed 10 jun 2006.

13. Rodriguez, L.L.; Letchworth, G.J.; Spiropoulou, C.F.; Nichol, S.T. (1993). Rapid detection of vesicular stomatitis virus New Jersey serotype in clinical samples by using polymerase chain reaction. $J$. Clin. Microbiol., 31, 2016-2020.

14. Thompson, R.C.A.; Constantine, C.C.; Morgan, U.M. (1998). Overview and significance of molecular methods: what role for molecular epidemiology? Parasitology, 117, 161-175.

15. World Organization for Animal Health. Manual of diagnostic test and vaccines for terrestrial animals. Available at: http://www.oie.int. Accessed 10 nov 2006. 